\title{
Archaeology for the Anthropocene: Scale, Soil, and the Settlement of Iceland
}

\section{$\underline{\text { Abstract }}$}

Archaeologists have devised numerous methods for measuring and describing past human-environmental interactions, but connecting historic case studies with present-day global concerns often proves challenging. New ways of considering scale are needed to bring case studies of past communities into productive conversation with the global Anthropocene. Iceland, one of the last land masses colonized by humans, was transformed by the agricultural practices of the first generations of Norse settlers in the 9th and 10th centuries, including a significant reduction in forest cover and soil loss to erosion. However, the large-scale, island-wide process of erosion manifested in different ways that become clear when changes in soil cover are investigated at the regional scale. These changes were beneficial in some places and detrimental in others, and the development of inequality was contingent on both social and environmental contexts. Scholars of the contemporary Anthropocene must likewise connect local effects, including landscape degradation and social inequality, to anthropogenic processes that operate beyond the scale of everyday experience. Social landscapes, including infrastructure and environmental degradation, act in concert with ecological processes to reconstitute the 'natural' into new, taken-for-granted landscapes of inequality. Studying the way past communities experienced relatively larger-scale anthropogenic environmental change leads to new ways of thinking about, and perhaps managing, human responses to contemporary global-scale change.

Keywords: Archaeology; Iceland; Climate change; Political ecology; Erosion; Landscape

\section{Introduction}

How can archaeology provide a contribution to the present and future of the Anthropocene? Multiple definitions and start dates have been proposed for the Anthropocene since the term was coined, including a recent volume of this journal that used archaeological evidence to demonstrate the significant impact of human activity on global environmental and geological processes throughout the Holocene (Braje 2015; Crutzen and Stoermer 2000; Erlandson and Braje 2013). In this paper, I use the term to denote that period during which human actions have directly led to changes in global-scale climatic systems which, if unchecked, threaten contemporary ways of life (Lewis and Maslin 2015; Steffen, et al. 2011). Kintigh, et al. (2014:15-19) listed Anthropocene research among archaeology's "grand challenges" for the $21^{\text {st }}$ 
century, calling for the discipline to "situate itself at the center of fundamental questions ... that are the focus of important international policy debate" (16). The archaeology of the Anthropocene then becomes a call to action, not only a geological epoch but primarily a political statement that situates present and future environmental degradation as a consequence of the Industrial Revolution and capitalist modernity (Braje and Erlandson 2013:120).

Foley, et al. (2013) introduced the term palaeoanthropocene to describe the diffuse, transitional period between early Holocene environmental modification by humans and the clear, global changes brought about by the Industrial Revolution. The palaeoanthropocene designation emphasizes regional human-induced environmental change, recognizing that pre-Industrial environmental change occurred around the world at different paces and scales, in different cultural contexts and by engaging different ecological processes. These changes may not have had immediate global impact, but caused significant alteration to local and regional landscapes. The palaeoanthropocene may therefore be understood to have begun at multiple times around the world. Iceland's palaeoanthropocene, the focus of the second half of this paper, began at the end of the $9^{\text {th }}$ century CE shortly after the island was first settled by Norse farmers (Streeter, et al. 2015). These periods of rapid, human-induced transition between different regional environmental regimes can be productively considered as earlier, smaller-scale analogues to the modern Anthropocene.

The discipline of archaeology is well suited to address questions of relevance to the Anthropocene, as by definition it investigates how people have both instigated and responded to changes in the material world around them throughout the span of human existence (see Braje and Erlandson 2013; Mrozowski 2011; Rockman and Flatman 2012). Archaeology has engaged questions of environmental interest since at least the 1950s, with the advent of cultural ecology 
research (Balée 2006; Butzer 1975; Crumley 1994; Reitz and Shackley 2012; Steward 1955).

Since that time, archaeologists have become well versed in creating environmental

reconstructions of past landscapes, and have developed nuanced understandings of the complex and interconnected relationship between human society and environmental change (e.g., Fisher, et al. 2009; Hilger, et al. 2015; Lentfer, et al. 2002; Melville 1990; Mrozowski 2006; Thurston 2009; Woodbridge, et al. 2012). From the late $20^{\text {th }}$ century to the present day, many archaeologists have addressed their work towards understanding how past societies have caused and responded to environmental challenges (e.g., Briggs, et al. 2006; Cooper and Sheets 2012; McGovern, et al. 2007). These are questions that can only be answered archaeologically, particularly for times and places when historical documentation is absent or sparse. Past examples of sustainability, resilience, and collapse abound in the literature; two of the most wellknown palaeoanthropocenes include deforestation on Easter Island (e.g. Rull, et al. 2013) and resource management and depletion among the ancient Maya (e.g. Chase and Scarborough 2014a; Robin 2006).

More recently, amid increasing concern about human responsibility for global climate change, the archaeology of environmental change has often been framed in terms of its potential to find solutions for contemporary problems, to "use a deeper understanding of the past to create a better future" (Costanza, et al. 2007:13; see also Chase and Scarborough 2014b; Fisher and Feinman 2005; Fisher, et al. 2009; Harrison and Maher 2014b; Rick et al. 2013:42). Armed with a database of environmental responses drawn from past examples, many archaeologists want their work to inspire concrete, actionable solutions to the problems of global change in the Anthropocene (e.g. Harrison and Maher 2014b:2-3). 

archaeology's long history of engagement with the environmental and ecological sciences (Lane 2015). In voices ranging from the plaintive to resolute, archaeologists have railed against what has been described as "the marginalization of our discipline" (Redman, et al. 2009:15): "Despite producing key data, archaeologists have largely been left out of this discussion" (Kintigh, et al. 2014:15); "in practice ... few synergies have materialized” (Redman 2005:70); "we still lack complete narratives and concrete ways in which we can make a contribution" (Fisher, et al. 2009:256); "what has kept this avenue of research from reaching its potential audience?" (Fisher and Feinman 2005:64). Despite decades of significant historical and archaeological research, scholars have not yet demonstrated that knowledge of the past is of vital importance in planning for a sustainable future (Braje 2015).

In this paper, I reflect on some potential causes of this disconnect between intention and action, and provide one possible solution. The major difficulty lies in making the leap from identification of historic human impact on the landscape to novel and actionable solutions for the present, particularly for issues of global import (Lane 2015). I suggest, first, that archaeologists are once again up against the problem of scale (Chadwick 2013; Crumley 2003; Harris 2006): the problems are global but the data set is local. The majority of palaeoanthropocene research addresses ecosystem change within sites and regions; applying the conclusions to Anthropocene changes at the scale of the biosphere is difficult and often problematic (Dasmann 1976). Second, the most effective archaeological research about past environmental change investigates precisely how long-term interaction between humans and their landscapes shaped and structured 
the range of possible social actions, integrating social processes into the observations and explanations of change (Hill 2009; Lane 2015).

Archaeology cannot tell the world how to halt climate change. However, a focus on the specific social causes of and responses to past environmental change may be able to demonstrate how and why contemporary problems often appear insurmountable. Environmental change in the past, as today, occurred at physical and temporal scales beyond the scope of everyday experience. As people interact with the local effects of large-scale environmental change, landscapes modified by human action and infrastructure can come to seem natural and commonplace (Brownlow 2006; Cronon 1991; Hayden 2012; Larkin 2013; Lefebvre 1991). Archaeological investigation can suggest how social and political factors, such as the management of agricultural spaces or unequal distribution of resources, shaped the way changing environments and landscapes were subjectively experienced during palaeoanthropocene transitions. Viewing the archaeological record through such a lens may open new ways to address contemporary responses to the experience of climate change, such as institutionalized denial and political paralysis. I conclude with a case study from North Iceland, to explore how such an archaeology might be practiced.

\section{The Problem of Scale}

Environmental research in archaeology often asks how people and societies have reacted to changing environments. The archaeological data that results from this approach can elucidate long-term cycles of change, and sometimes determine the ultimate cause for observed environmental changes within a particular locale. This leads to conclusions that are both complex and historically specific. Archaeological research has repeatedly shown that when faced with 
environmental change, anthropogenic or otherwise, people react in ways that make sense within their particular social, political, and environmental context. These actions may or may not lead to the long-term survival of the society (Correia 2013; Ensor, et al. 2003). However, while socioenvironmental interactions within each particular archaeological case study can be made legible, the results are rarely actionable in the present. There is often a mismatch in both spatial and temporal scale between the problems of modern climate change and the data set that results from an archaeological investigation. For such research to be effective, the two scales must be mutually intelligible (Crumley 2003). One way in is to focus on scale itself, to recognize that environmental change and individual practice operated at difference scales in the past, just as they do today.

At relatively small scales, from the local to the regional, standard archaeological methods and questions have sometimes provided actionable suggestions. When a direct historical connection exists between past and present landscape practices, archaeology can provide an understanding of how long-term cycles of change have led to the present circumstances, which can sometimes suggest strategies for reversing or mitigating those specific changes (e.g. Lansing 2007; Redman, et al. 2009; Streeter and Dugmore 2013; Van de Noort 2013). These successes are rare, confined to regions near or very similar to the archaeological site, and provide actionable strategies only at the scale of the local community.

It therefore may be that archaeology's most powerful intervention will be to work with local communities to manage resources in a way that is coherent with the past and present and is sustainable over the long term (Atalay 2012; Fisher and Feinman 2005; Hicks, et al. 2014; Logan 2013; Stump 2013; Van de Noort 2013). A policy recommendation applicable at the global scale therefore might be that local communities must be at the center of any initiative aimed at long- 
term survival. Greater collaboration between archaeologists and community groups to foster both heritage preservation and environmental sustainability will likely be a vital part of shaping Anthropocene futures, but will require a sustained commitment to action at the community scale. This means a greater emphasis on connecting ongoing community archaeology initiatives with environmental questions and concerns.

Difficulties arise when a case study of environmental archaeology fits neither the causal nor cyclical chains of modern environmental degradation. This may happen when the solutions provided by archaeological research are not applicable in the local community because the intervening environmental and social changes have been too great, and/or when the conclusions of archaeological research are specific to a particular place and time, and lack broader relevance when lifted out their historical context. Often, the recommendations drawn from this work are general, along the lines of affirming that a sustainable society is indeed possible; or they echo the recommendations that ecologists have long advocated, such as the institution of resource management practices that are mindful of the environmental, social, and landscape context (e.g. Kennett and Beach 2013; McGovern, et al. 2007).

There is unquestionably value in providing hope for a sustainable future and in verifying that certain kinds of management have been successful in the past. Both cultural heritage and academic scholarship benefit immensely from greater knowledge of the past for its own sake, whether or not it speaks immediately to important issues in the present. But when the goal is to provide guidance for modern problems, the specificity of archaeological results makes it difficult for policy makers to look directly to archaeological research for innovative solutions. In terms of providing guidance and novel, actionable solutions for the present global environmental crisis, archaeologists have essentially spent the last few decades learning, time and again, what was 
already recognized in the 1960s: that social and ecological factors must be understood as complex and fundamentally related. While numerous research projects in environmental archaeology have been groundbreaking within the field and have dramatically advanced the state of knowledge of past human-environment interaction, the results lack significant impact when broadened to the global, contemporary scale. Claims that archaeological research can provide direct, actionable suggestions for surviving the Anthropocene remain to be "substantiated rather than simply asserted" (Lane 2015:2). Bringing local or regional data sets to bear on global-scale issues will require a fundamental change to the questions that archaeologists are prepared to ask of the material record of the past (Redman, et al. 2009; van der Leeuw 2014). To build more effective connections between the past and present, the focus should be on processes and principles from the past that are analogous to contemporary experience.

\section{New Questions: An Archaeology of Climate Change Denial?}

Archaeological research is often motivated by the idea that collecting more data about palaeoanthropocene transitions will lead to better models, which will help us predict and alter the future of human-environment interaction at both local and global scales (e.g. Costanza, et al. 2007; Fisher and Feinman 2005; Young, et al. 2007). This has worked within other disciplines: the development of better environmental models by historical ecologists has led to improved predictions of global temperature and sea level rise, for example (Ogilvie 2010). But the specificity of archaeological data has not led to models that can better predict future social practice (e.g., Caseldine and Turney 2010).

The major problem of the Anthropocene is not that humans and our institutions lack the knowledge to manage or mitigate climate change, or that we lack a historically situated 
understanding of its causes and effects. Human activities, especially the burning of fossil fuels over the last several centuries, have altered the climate to the extent that major increases in temperature, sea level, and catastrophic weather events are already occurring and are virtually certain to continue over the next century (IPCC 2014). However, these increasingly accurate predictions of environmental scientists have not led to concerted, definitive action towards climate mitigation. Strategies that could lead to a more sustainable present and future are widely known, but have not been implemented. This includes the application of new technologies and management strategies, such as the use of renewable energy sources or the institution of strong carbon reduction policies. More fundamentally, significant economic and political changes have the potential to slow or halt global warming, from encouraging the consumption of locallyproduced food to abandoning the capitalist ideal of perpetual economic growth (Klein 2015). The implementation of these and other changes will be complex and difficult, and is likely to require a dramatic shift in the way humans understand our relationship to the world. However, despite significant challenges, changes will not be implemented without the support of political and economic leaders; this support has not been forthcoming.

How can it be that humans as a species know so much about what we have done to our planet, yet are incapable of doing anything about it? What humanity appears to lack is the collective will to change our environmental practices, informed by a strong sense of denial, especially in the developed world. Gisli Pálsson and colleagues have characterized Anthropocene societies as "involving humans being basically in conflict with themselves through the structures and systems that they have themselves created in order to improve their lifestyles" (2013:8). Similarly, sociologist Kari Norgaard sees the fundamental problem of climate change not as "lack of information or of caring" but of "apathy as suffering" (2011:222), the result of a 
disconnect between everyday consumption practices and the horrific consequences that befall other people, somewhere else. This includes an understanding that modern lifestyles are built upon social injustice and environmental devastation, and the guilt that emerges as paralysis, denial, and inaction, clinging to a constructed innocence. What the Anthropocene requires is a shift in global consciousness, to break out of the "socially organized denial" (Norgaard 2011:207) that produces a collective lack of response, to break down the "disconnect between insight and action" (Palsson, et al. 2013:7) and transform suffocating anxiety into positive response. Without such a shift in human consciousness and subjectivity, the known technological, economic, and social strategies for mitigating the effects of climate change stand little chance of being implemented at a wide enough scale to be effective.

It is here that I believe archaeology can and should intervene, towards reshaping the way humans understand our relationship to the landscape. Archaeology primarily deals with data sets that contain material evidence of past environments and actions, and therefore has become adept at describing past environmental challenges, solutions, and failures. Once these basic questions about past environmental change have been answered, questions about the social and subjective experience of changing landscapes can be addressed. Archaeological theory provides numerous conceptual tools to use the material record of the past to address the subjective experience of living through palaeoanthropocene transitions, which can help to understand how contemporary humans are experiencing the Anthropocene. In particular, the principle of scale provides a comparative link between past and present experience. Relevant research questions might include: How did large-scale environmental change affect the everyday lives of households and individuals? Was environmental change obvious or obscured, and why? Were solutions clear and 
easily implemented, or contentious and difficult? What particular social and political factors made those specific actions appropriate?

The modern, subjective responses of apathy and inaction are socially constructed and built upon the material realities of our political economic system: where do resources come from, how are they altered into products, how are they distributed through society? Who makes those decisions and who suffers as a result? Perhaps most importantly, when and to whom does this economic and political activity become invisible? Sociopolitical context, ideology, and repeated engagement with the materiality of the landscape are fundamentally tied to the formation of human subjectivity (Bourdieu 1980; Ingold 1993; Johnson 2012; Lefebvre 1991). That is to say, a person's sense of their own place within a society and the power or agency that they wield to enact change is inseparable from the way the society extracts, acquires, and distributes resources across the landscape (Earle 2002). These fundamentally material questions of economic practice and social difference are a traditional focus of archaeological scholarship. Resource production in the past has often left highly visible signatures in the landscape, and social differences can be readily apparent through comparison between the material culture evidence from multiple sites and households (Einarsson 2015; Hodder and Cessford 2004; Lightfoot, et al. 1998; Wilson 1989). Archaeologists are also well practiced at understanding how the physical, material environment shapes practice both at individual and societal scales. Archaeology therefore has the conceptual tools to investigate how a particular political-economic system leads to the construction of a physical, material landscape that encourages action - or inaction - in the face of environmental crisis (e.g. Hill 2009).

To rise to this challenge, archaeologists need to reconsider what we hope to learn from our questions. Particular knowledge about the past may never have more than a limited ability to 
answer specific questions about the present. More general questions about social processes and differences in scale may not provide answers that are universally applicable, but with care, they can be used to think through modern problems. If the material record of past activity can be used to demystify the way that built and degraded landscapes mutually constitute economic and political practice, archaeology may lead to ways of constructing landscapes in the present that shape positive, rather than negative, action (Catlin and Lash 2014). To explore how archaeology might mobilize these ideas in practice, I will discuss the example of soil erosion in Iceland.

\section{A Palaeoanthropocene in Iceland}

No humans lived in Iceland until around the year $870 \mathrm{CE}$, when Norse settlers began arriving from Scandinavia. The effects of the settlement on the landscape as a whole were rapid and dramatic. The early settlers actively deforested the land, cutting trees for fuel, construction material, and to clear land for fields (Smith 1995). They also put their livestock to pasture in the forests and the highland. Iceland's soils, mostly volcanic andosols, are highly susceptible to erosion, and the combined pressure from deforestation, grazing, and countless foraging hooves caused significant soil loss that continues through the present day (Figure 1) (Arnalds 2004; Thórhallsdóttir, et al. 2013). Estimates have suggested that over the 1100 years since the settlement, Iceland has lost more than $90 \%$ of its woodland cover and up to $40 \%$ of its soils (McGovern, et al. 2007:29; Streeter, et al. 2015:9). It is in part this clearly definable transition between a landscape without human modifications and an anthropogenic landscape that makes Iceland an attractive place to study historic human impacts on the environment: a palaeoanthropocene transition made visible (e.g. Harrison and Maher 2014a; Streeter, et al. 2015). 
Figure 1. Erosion front on Flótsheiđi, North Iceland. Photo (C) K. Catlin 2015.

These anthropogenic environmental changes have sometimes been characterized as "raiding the landscape" (Amorosi, et al. 1997), rampaging Vikings thoughtlessly destroying that which they needed to survive, an important warning for the modern world. However, more recent work has suggested that the early Icelanders in fact did manage the landscape effectively. Numerous scholars have shown how the early Icelanders adapted their agricultural practices in ways that made coherent sense within the altered landscape (e.g. Catlin and Bolender in press; Dugmore, et al. 2006; McGovern, et al. 2007; Thomson and Simpson 2006; Vésteinsson and McGovern 2012). In fact, the alterations made to the landscape may have been essential to creating a sustainable way of life, and indeed, many Icelandic farmsteads have thrived over the last thousand years. The deforested landscape was highly amenable to growing hay to feed cows 
and sheep through the winter, and community-level management of pastures helped to maintain them through the centuries. Icelandic agriculture, within a transformed palaeoanthropocene landscape, has been for the most part sustainable over the course of a millennium.

But the environmental processes that were set in motion by the agricultural practices of the settlement in the late $9^{\text {th }}$ century had unforeseeable, long-term consequences, through the $19^{\text {th }}$ century and into the present. Recent work on environmental reconstruction has shown that while both deforestation and erosion increased after the settlement, the extent of both processes varied significantly at different places across the island. In many locations the most dramatic landscape changes occurred after ca. 1300 or even as late as the $19^{\text {th }}$ century, long after the initial impact of a human and agricultural presence (Streeter, et al. 2015). The late $19^{\text {th }}$ and $20^{\text {th }}$ centuries in particular saw a huge increase in the scale of sheep farming, a response to the demand of international wool markets, which had a significant impact on highland erosion (Thórhallsdóttir, et al. 2013). 

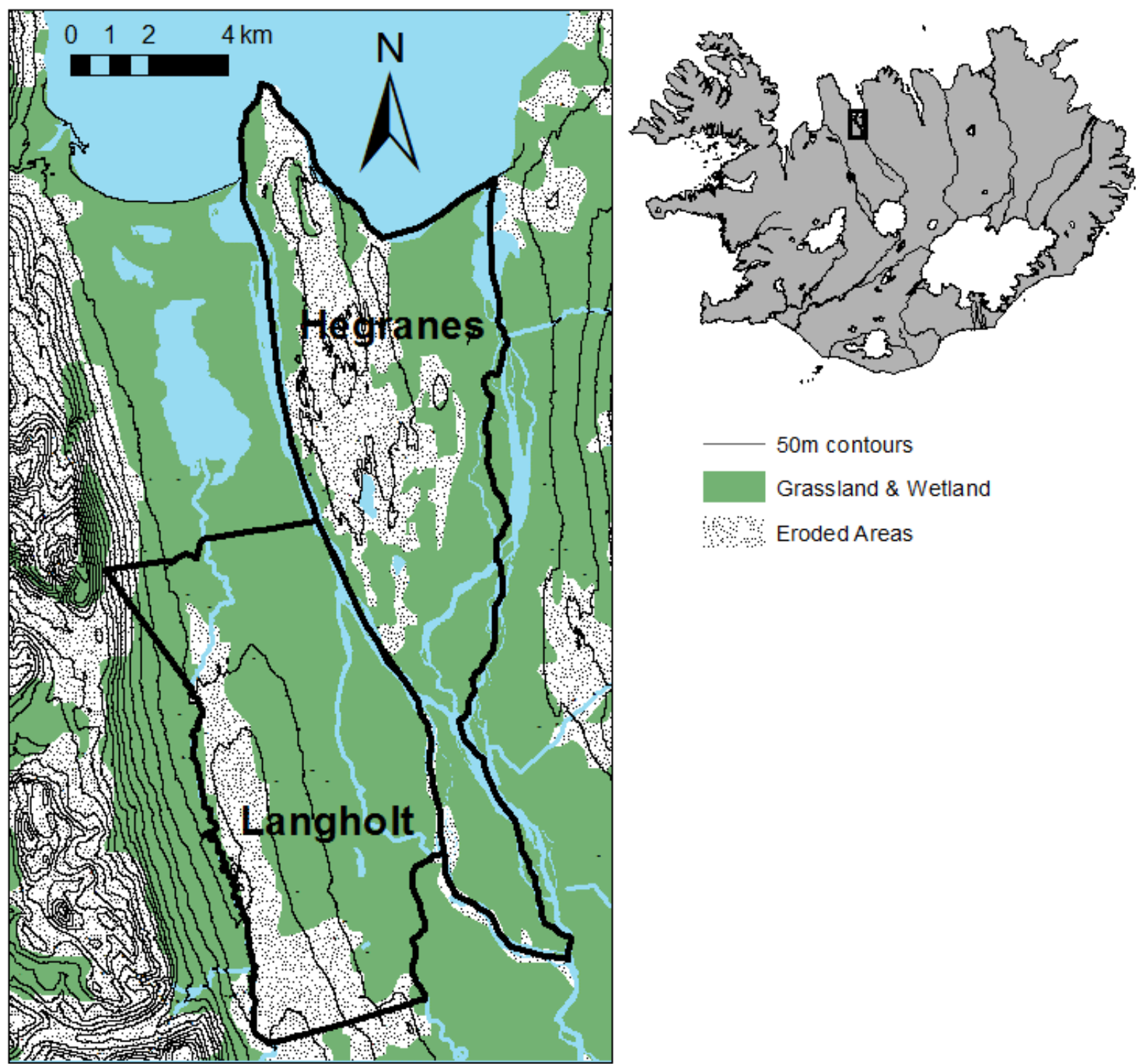

Figure 2. Location map of Langholt and Hegranes. Land cover data CLMHI.

\subsection{Skagafjörður, North Iceland}

From 2001-2014, the Skagafjörður Archaeological Settlement Survey worked to characterize the settlement sequence of Langholt, North Iceland, a fertile lowland region that has been actively and continuously farmed since the late 9 th century (Figure 2). I and other researchers used soil cores to collect stratigraphic data from over 3000 point locations in and around historic fields (Figure 3) (Steinberg, et al. in press). Iceland's long history of volcanism 
has distributed recognizable, datable ash layers through the soil, and the amount of soil deposited between each layer was used to measure change and variation in sediment deposition across the landscape and through time (Catlin 2011; Dugmore, et al. 2009; Pórarinsson 1944). The average sediment deposition rate in the 1100 years after settlement was $4 \mathrm{~mm} / \mathrm{year}$. Before settlement, it was $0.6 \mathrm{~mm} / \mathrm{year}$. The rate of soil accumulation increased by a factor of 6 as a direct result of human activities on the land.

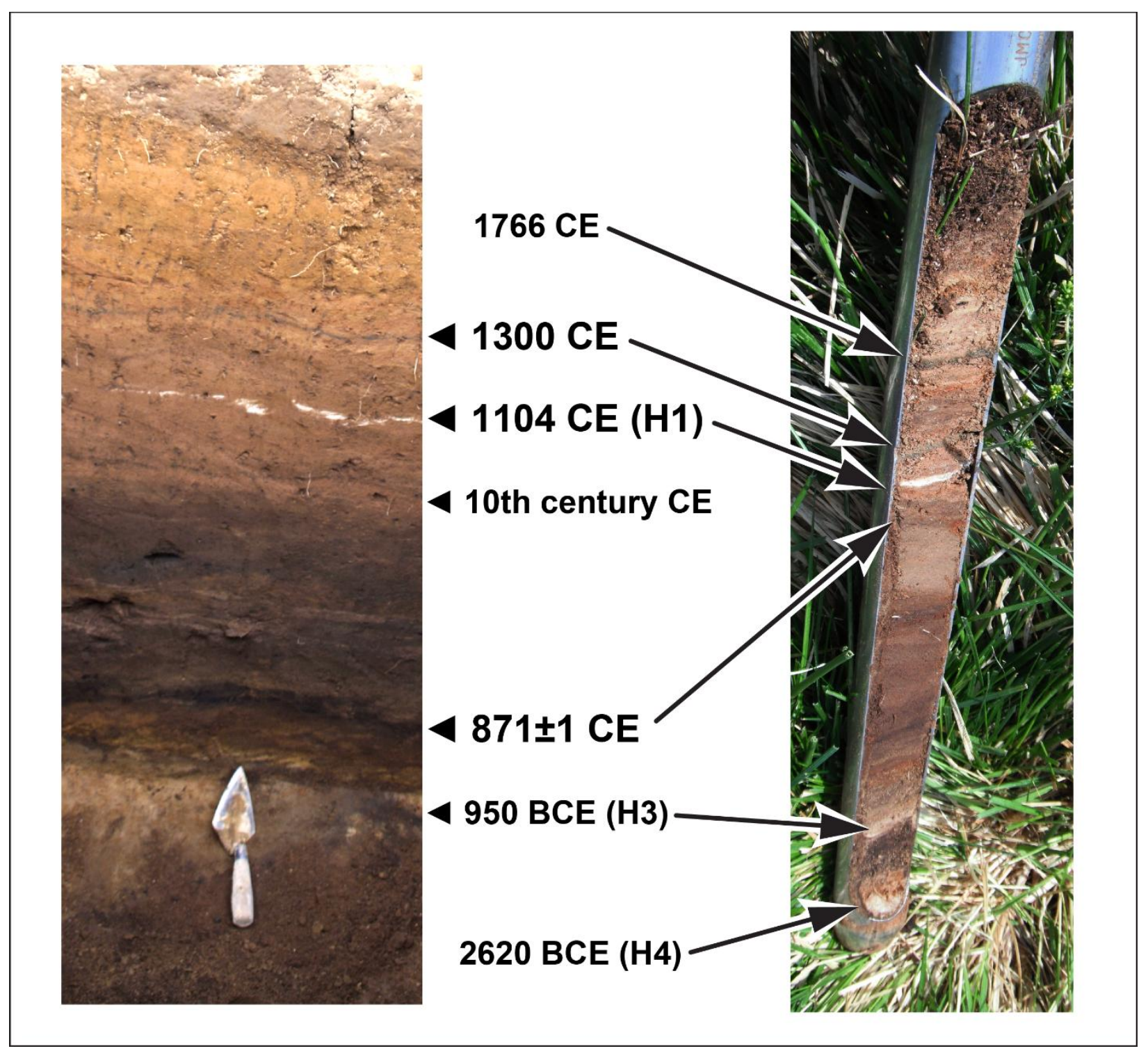

Figure 3. Soil core and profile from Langholt, showing tephra layers and sediment accumulation. 
Langholt as a region has experienced a net increase in sediment deposition, rather than soil loss, as an effect of erosion. Although all farms experienced high sediment accumulation rates and farmstead abandonment was rare, the fields of wealthy, successful farms accumulated slightly deeper soils over time than other areas within Langholt (Catlin 2011; Catlin in preparation). These successful farms were relatively large, were founded early, and were subdivided over time to create smaller farms (Bolender 2012; Bolender, et al. 2008; Steinberg, et al. in press).

The Skagafjörður Church and Settlement Survey began work on Hegranes, a neighboring region to Langholt, in 2015. Hegranes is more marginal and rocky, exhibiting patches of deep soil interspersed with areas that have eroded down to glacial gravel or bedrock (Figure 2). The region is home to numerous farms that have been productive from the settlement to the present day. In the environmentally marginal spaces at the edges of these successful farms lie the ruins of abandoned agricultural structures. These places were variously dependent farmsteads, sheepfolds, shielings, or areas of specialized production, and likely served multiple purposes between periods of abandonment. Medieval Icelandic agriculture depended on a homefield, an area around the main farm buildings in which high quality hay was grown, protected by a turfbuilt fence (Einarsson 2015). The majority of abandoned, marginal places on Hegranes also include evidence of turf walls enclosing a field around the structures.

Preliminary work suggests that in Hegranes' marginal landscape, field walls could be extremely effective at maintaining deep, productive soils over time (Figure 4). Furthermore, evidence of occasional use of marginal infrastructure over long time periods suggests that people returned again and again over centuries to those areas where walls and buildings had been constructed, at a remove from the central farm. In contrast to more uniform Langholt, on 
Hegranes it appears that the residents of major farms managed the marginal edges of their land in different ways. The marginal sites at the edges of some properties show evidence of long-term settlement and habitation, while on other properties, the marginal places have little indication of regular habitation. Higher-status farming households may have had the environmental and labor resources to establish fully functional smaller-scale dependent or satellite farms, while others lacked the resources to spare labor from the central farmstead.

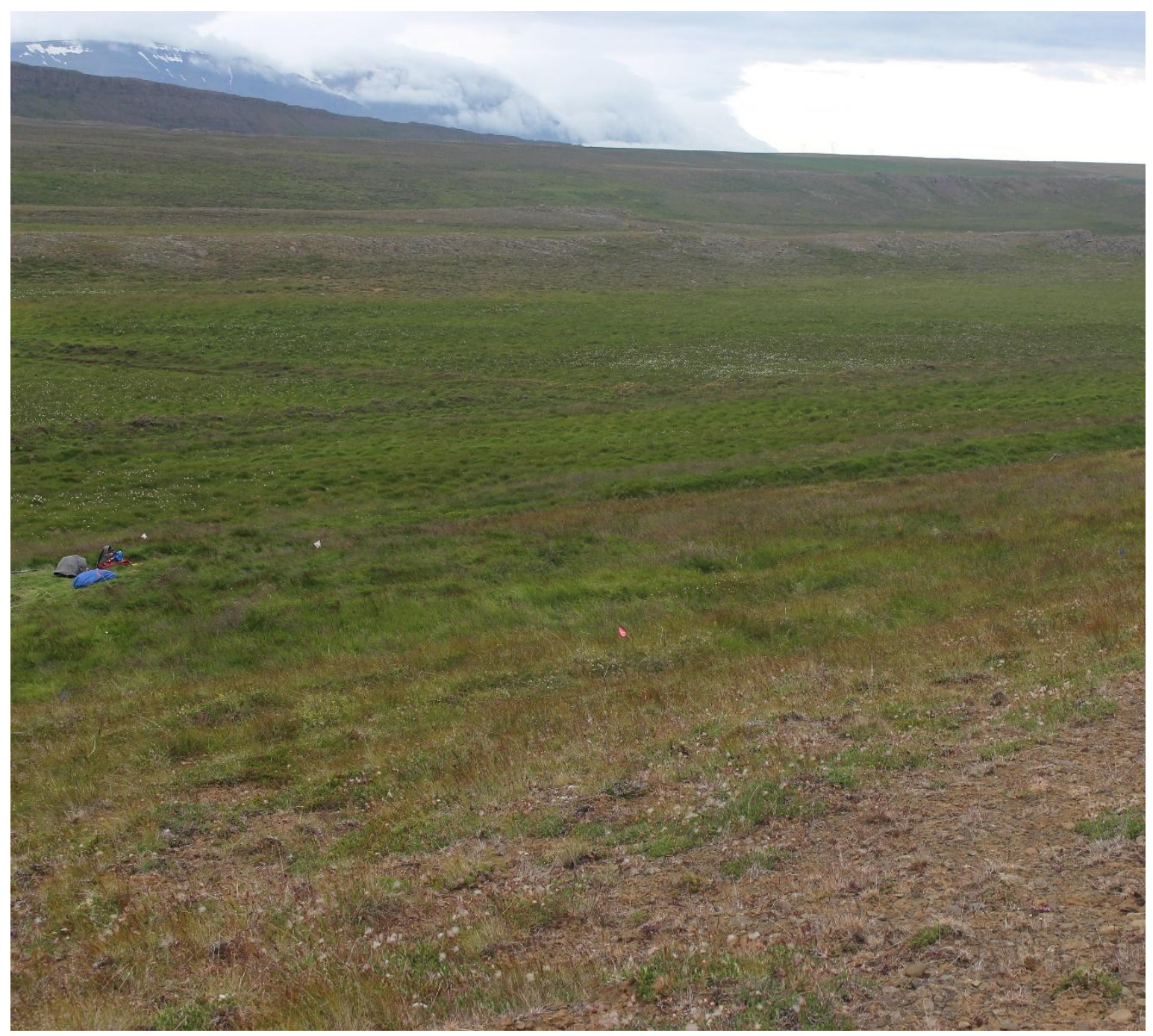

Figure 4. Erosion at an ecologically marginal settlement on Hegranes. Foreground: eroded land. The backpacks sit atop a probable $19^{\text {th }}$ century sheepfold. A medieval turf wall (from bottom left to center right, includes the pink flag) separates grassy, deeper soils from eroded areas. Photo (C) K. Catlin 2015. 


\subsection{Erosion, Infrastructure, and Landscape}

Erosion and its consequences were maintained, supported, and accelerated by complex interactions between environmental processes and social practices, constituting an Icelandic palaeoanthropocene. Icelandic erosion can be productively thought of as a large-scale process that shaped everyday experience, in an analogy with contemporary global change. Understanding past erosion in this way has the potential to generate suggestions for the future of the Anthropocene that are generalizable, yet novel, and dependent on archaeological insights.

The soil that was deposited in lowland areas like Langholt largely originated in the highland, where the effects of overgrazing were most profound. Some of this soil also may have come from settlements at the highland margin, or from closer, patchier regions like Hegranes. While some lowland farmers in Iceland were gaining significant amounts of soil, those who lived on the margins were abandoning their farms and moving closer to the coastal lowlands and the farms that would continue to be successful through the present day. Whether farmstead 
abandonment in marginal areas was directly due to environmental change or to other social factors is an open question, and probably varied from region to region (Dugmore, et al. 2006; Vésteinsson, et al. 2014). Regardless of the reason for moving, productive farmland in the lowlands had long been claimed by the highland retreat of the $11^{\text {th }}$ century. Refugees from marginal areas would have had little choice but to attach themselves to lowland farms as servants or itinerant laborers, a significant loss of self-determination in comparison to life as independent farmers on the margins.

A tenant-landlord social system based on hay production and pasture exploitation depended on a constructed landscape of field boundaries, cleared pastures, and farm buildings. The infrastructure of the farm, the placement of the field and buildings within the landscape and the cycles of work required to maintain them, made the farm into a permanent feature of the landscape, an unalterable fact, a vital part of the human landscape (Catlin and Bolender in press). The processes of erosion interacted with this constructed landscape as it destroyed, augmented, or altered the fields. Where erosion augmented fields, such as on Langholt, the effects of erosion were obscured, and productivity may even have increased. On Hegranes, where people repeatedly returned to and repurposed places where old infrastructure held back the tide of erosion, the infrastructure itself became the natural resource, until eventually it too was abandoned. When these long-term dependable resources finally became unusable, likely during or after the $18^{\text {th }}$ century, there was nowhere left to go, except to contract the infrastructure and resources of the farmstead into a central productive area. The failure of a dependent farmstead meant that former tenants had to be moved permanently onto the land of the central manor, decreasing their household autonomy, and increasing poverty rates. 
Erosion can sometimes occur rapidly, during a storm or flood, or when the landscape is already in an advanced stage of soil loss. But when erosion proceeds at the slow rates we observed in cores and profiles, a few millimeters per year, it cannot be directly touched or perceived on a human scale. The effects of erosion can be observed and measured, as areas of bare rock or deeper soils on lowland farms. But erosion depends on countless factors at multiple scales, including decisions made by the first settlers and their descendants through the centuries, the footsteps of individual sheep in the highland, the volcanic history of the region, prevailing winds on a given day, Europe's demand for wool, and laws that defined who was allowed to farm, where and how walls could be built, and where and when animals could graze.

With every new attempt to define, describe, and explain erosion, other objects, networks, and practices are implicated. Much like global climate change, erosion recedes from attempts to grasp it. Erosion is always already there, overshadowing all everyday interactions between people and things, but only a small part of its effects is available to the senses at a given time (see Morton 2013). Erosion obscures its own changes to the landscape so they do not obviously appear as the result of human action, but rather an act of God or simply the way the landscape is. And yet erosion is real, it is caused by humans, it profoundly alters the landscape, and it impinges on everyday interactions. These everyday actions include the placement and construction of walls, the seasonal movement of sheep, and even erosion mitigation efforts of the $20^{\text {th }}$ and $21^{\text {st }}$ centuries (Crofts 2011). The choice to return each summer to a shieling where the grass is high and good is not itself erosion, nor is the final clump of vegetation as it disappears into the mouth of a sheep, nor rising water levels in the river, a displaced householder looking for work, or $21^{\text {st }}$ century volunteers planting new trees: but erosion adheres to every act, disconnected but hovering just out of grasp. 
Through those everyday interactions, erosion influenced the development of a seemingly natural social landscape that included significant inequality. Powerful households, owners of farms that benefited from increased soil, were in a position to reuse abandoned infrastructure and to exploit the labor of formerly autonomous farmers. This inequality also came to seem as natural as the eroded landscape. The landscape was maintained through the labor of lower status individuals, who likewise depended on the land for their work and survival: the degraded environment and the dispossessed people interlocked with one another to constitute the landscape as it had been and would continue to be (Mitchell 2003). Social and agricultural organization acted in concert with the palaeoanthropocene landscape to shape subjectivities that would maintain social inequality and agricultural sustainability over the course of centuries (Catlin and Bolender 2013).

By the $18^{\text {th }}$ and $19^{\text {th }}$ centuries, well into the contemporary Anthropocene, sheep farming and resource exploitation were increasing, the eroded landscape had come to seem natural and disconnected from agricultural practices, and the relative poverty of the majority of the population had been a given fact since the time of saga and legend. The ecological reasoning behind the landscape management strategies of the early settlers was therefore easily overlooked in the face of a lucrative wool market. The past labor that had created the landscape was forgotten, congealed into a 'second nature' (Catlin and Bolender in press; Cronon 1991), reinforced and augmented by the agricultural practices that the infrastructure encouraged, always connected by and through erosion. There was apparently no reason not to double, triple, quadruple the herds of sheep. Through the $19^{\text {th }}$ and early $20^{\text {th }}$ centuries, the rich got richer, erosion got worse, the poor got poorer, and still the human connection to degradation was obscured. 


\section{Conclusion}

It remains to bring this discussion back to the beginning: the contribution of archaeology to Anthropocene issues, specifically global climate change and social paralysis that accompanies it. How might approaching the archaeology of environmental change through a composite lens derived from political economy and the construction of subjective experience lead to actionable suggestions for the challenges of the Anthropocene?

In Iceland, erosion constantly impinged upon everyday life as part of a constructed landscape, but did not become a part of social consciousness until the $20^{\text {th }}$ century, when it overwhelmed the infrastructure that had been designed to exploit the soil (Crofts 2011). In an analogous contemporary context, the significant infrastructure that extracts and distributes energy from fossil fuels (including electrical substations, power lines, and wall sockets) constitutes part of the constructed, seemingly natural landscape that is tied to the large-scale, omnipresent thing called global climate change. The infrastructure is so much a part of our world, and so much a part of an economic structure that fosters social inequality, that the idea of changing it seems alien or even impossible. This infrastructure is barely noticed, disconnected from everyday consciousness and from the damage it causes in other places and at different scales. Nonetheless, its function is to continue and expand the processes of resource consumption and environmental degradation. As long as the infrastructure functions, and as long as those who control it continue to benefit economically, there is no incentive to change - no reason to even consider that a change is necessary. One suggestion is to question the invisible infrastructure that conditions us to accept the world as it is, infrastructure that acts to "make seem inevitable what is really contested" (Hayden 2012:10). 

dispositions away from sustainable practices. In Iceland, walled fields and deeper soils were vital for the production of hay and the support of livestock, and arguably enabled sustainable agriculture over a thousand years. But this same infrastructure, as it came to seem less of a human creation and more an inevitable part of the landscape, also encouraged the continuation and eventual escalation of agricultural practices that led to increasingly destructive erosion, including the increase in highland grazing through the $19^{\text {th }}$ century. Similarly, today, networks of unwalkable highways and electricity universally available at the push of a button encourage the consumption of fossil fuels in ever greater quantities, by disconnecting everyday activities from the environmental degradation they cause.

If archaeology is to be relevant to the future of the Anthropocene, the scope of the questions must be able to relate to the scale of the data. This may mean devoting significant time and attention to community archaeology, by focusing on local-scale questions about environmental management in the present. While these engaged archaeological projects may ultimately add up to changes much larger than a single community, not every project can do this kind of work, and the kinds of questions that can be effectively addressed by community projects are significantly different from those that can be asked by archaeologists taking a broadly comparative approach to landscape change. Most archaeological work will continue to be framed in terms of its potential to address problems beyond the local, especially when centuries of environmental and social change separate the study period from the contemporary community. To substantiate claims that our discipline can have a significant impact on national or global discussions about climate change, a re-framing of the goals and questions is of vital importance. 
Asking questions of the past that refocus attention away from site-specific details and towards relationships between humans and their landscapes can help connect the past to the future. One way to connect material evidence to subjective experiences involves using principles like scale as an analytic and comparative lens, rather than a problem to be avoided or worked around.

Thinking of Icelandic erosion as a multiscalar, socially embedded process provides the flexibility of scale to connect an island-wide ecological, anthropogenic process to individual subjectivities and the production of social inequality, without reducing either to over-generalized or hyper-specific conclusions. The variable causes and effects of erosion at multiple locations and scales can be considered as distinct but connected processes, part of social and economic networks that are global, local, and individual, connecting the medieval European economy to the management of a single farmstead to the choices made by a farmhand on a given day. Thinking about erosion in this way offers a starting point from which to address the subjective experience of erosion in the past, to understand how individuals were shaped by a degraded anthropogenic landscape, and why that landscape seemed normal and unquestionable.

Archaeological method and theory makes it possible to trace inequality through subjectivity, to landscape, to political economy, to environmental change, and back again. Through the archaeology of palaeoanthropocenes like Iceland's, examples of large-scale environmental change can be viewed with hindsight, from their beginning through their complex relationships with human society over very long time scales. These insights can help to think through modern responses to environmental changes that are still in progress, and perhaps suggest some material and infrastructural interventions that might help better comprehend and adjust subjectivities, to shape the paradigmatic, epistemic shift that will be necessary for the future of the Anthropocene, if it is to have one. 
Having shown that anthropogenic environmental change occurred and was dealt with either well or poorly in the past, an archaeology for the anthropocene should focus on collection, comparison, and synthesis of case studies that show how environmental practices were politically shaped - to learn not just what people did, but how the power embedded in the landscape encouraged them to do it. Data that materially connects environmental change to constructed landscapes to social practice may turn out to be more effectively generalizable across temporal and spatial scales than specific details about agricultural or environmental management choices. As specialists in the material world, the relationship between people and things, archaeologists have an opportunity to contribute to the most basic problem of the Anthropocene: to advocate for change not only in the actions we take, but for change in the way that we think.

\section{REFERENCES CITED}

Amorosi, Thomas, et al.

1997 Raiding the Landscape: Human Impact in the Scandinavian North Atlantic. Human Ecology 25(3):491-581.

Arnalds, Olafur

2004 Volcanic soils of Iceland. Catena 56(1-3):3-20.

Atalay, Sonya

2012 Community-Based Archaeology: Research With, By, and For Indigenous and Local Communities. Berkeley: University of California Press.

Balée, William

2006 The Research Program of Historical Ecology. Annual Review of Anthropology 35(1):7598.

Bolender, Douglas J.

2012 Dividing Land and Creating Class: The Development of a Landlord-Tenant Political Economy in Medieval Iceland. In The Anthropological Study of Class and Consciousness. E.P. Durrenberger, ed. Pp. 65-83: University Press of Colorado. 
Bolender, Douglas J., John M. Steinberg, and E. Paul Durrenberger

2008 Unsettled Landscapes: Settlement Patterns and the Development of Social Inequality in Northern Iceland. In Economies and the Transformation of Landscape. L. Chiggett and C.A. Pool, eds. Pp. 217-238. Lanham, MD: AltaMira Press.

Bourdieu, Pierre

1980 The Logic of Practice. Stanford: Stanford University Press.

Braje, Todd J.

2015 Earth Systems, Human Agency, and the Anthropocene: Planet Earth in the Human Age. Journal of Archaeological Research 23(4):369-396.

Braje, Todd J., and Jon M. Erlandson

2013 Looking forward, looking back: Humans, anthropogenic change, and the Anthropocene. Anthropocene 4:116-121.

Briggs, John M., et al.

2006 Why Ecology Needs Archaeologists and Archaeology Needs Ecologists. Frontiers in Ecology and Environment 4(4):180-188.

Brownlow, Alec

2006 An archaeology of fear and environmental change in Philadelphia. Geoforum 37(2):227245.

Butzer, Karl W.

1975 The Ecological Approach to Archaeology: Are We Really Trying? American Antiquity 40(1):106-111.

Caseldine, C. J., and C. Turney

2010 The bigger picture: towards integrating palaeoclimate and environmental data with a history of societal change. Journal of Quaternary Science 25(1):88-93.

Catlin, Kathryn A.

2011 A Viking Age Political Economy from Soil Core Tephrochronology, University of Massachusetts Boston.

Catlin, Kathryn A., and Douglas J. Bolender

2013 Second Nature: Icelandic Landscapes of Social Inequality. In 112th Annual Meeting of the American Anthropological Association. Chicago, IL. 
in press Were the Vikings Really Green? Environmental Degradation and Social Inequality in Iceland's Second Nature Landscape. In Uneven Terrain: Archaeologies of Political Ecology. J.K. Millhauser, C.T. Morehart, and S. Juarez, eds: Archaeological Papers of the American Anthropological Association.

Catlin, Kathryn A., and Ryan P. Lash

2014 Necessary Landscapes: Examining Sustainability in Two Marginal Environments in the North Atlantic. In 113th Meeting of the American Anthropological Society. Washington, DC.

Chadwick, Adrian

2013 Some Fishy Things About Scales: Macro- and Micro-approaches to Later Prehistoric and Romano-British Field Systems. Landscapes 14(1):13-32.

Chase, Arlen F., and Vernon Scarborough

2014a 1 Diversity, Resiliency, and IHOPE-Maya: Using the Past to Inform the Present. Archeological Papers of the American Anthropological Association 24(1):1-10.

2014b Forward. Archeological Papers of the American Anthropological Association 24(1):vvi.

Cooper, Jago, and Payson Sheets

2012 Surviving Sudden Environmental Change: Answers from Archaeology. Boulder: University Press of Colorado.

Correia, David

$2013 F^{* *} \mathrm{k}$ Jared Diamond. Capitalism Nature Socialism 24(4):1-6.

Costanza, Robert, Lisa J. Graumlich, and Will Steffen

2007 Sustainability or Collapse: Lessons from Integrating the History of Humans and the Rest of Nature. In Sustainability or Collapse? : An Integrated History and Future of People on Earth. R. Costanza, L. Graumlich, and W.L. Steffen, eds. Pp. 3-17. Cambridge, MA: MIT Press.

Crofts, Roger

2011 Healing the Land: The Story of Land Reclamation and Soil Conservation in Iceland: Soil Conservation Service of Iceland.

Cronon, William

1991 Nature's Metropolis: Chicago and the Great West. New York: W. W. Norton \& Co. Crumley, C. L. (ed.) 
1994 Historical Ecology: Cultural Knowledge and Changing Landscapes. Santa Fe: School of American Research Press.

Crumley, Carole

2003 Historical Ecology: Integrated Thinking at Multiple Temporal and Spatial Scales. In World System History and Global Environmental Change. Lund University, Sweden.

Crutzen, P. J., and E.T. Stoermer

2000 The Anthropocene. Global Change Newsletter 41:17-18.

Dasmann, Raymond

1976 National Parks, Nature Conservation and 'Future Primitive'. Ecologist 6(5):164-167.

Dugmore, Andrew J., et al.

2006 An Over-Optimistic Pioneer Fringe? Environmental Perspectives on Medieval Settlement Abandonment in Pórsmörk, South Iceland. In Dynamics of Northern Societies: Proceedings of the SILA/NABO Conference on Arctic and North Atlantic Archaeology, Copenhagen, May 10-14, 2004. Pp. 335-345, Vol. 44. Copenhagen: Aarhus University Press.

Dugmore, Andrew J., et al.

2009 Conceptual Models of 1200 years of Icelandic Soil Erosion Reconstructed Using Tephrochronology. Journal of the North Atlantic 2:1-18.

Earle, Timothy

2002 Bronze Age Economics: The Beginnings of Political Economies. Cambridge: Westview Press.

Einarsson, Árni

2015 Viking Age Fences and Early Settlement Dynamics in Iceland. Journal of the North Atlantic 12(27):1-21.

Ensor, Bradley E., Marisa O. Ensor, and Gregory W. De Vries

2003 Hohokam Political Ecology and Vulnerability: Comments on Waters and Ravesloot. American Antiquity 68(1):169-181.

Erlandson, Jon M., and Todd J. Braje

2013 Archeology and the Anthropocene. Anthropocene 4:1-7.

Fisher, Christopher T., and Gary M. Feinman

2005 Introduction to "Landscapes over Time". American Anthropologist 107(1):62-69. 
Fisher, Christopher T., J. Brett Hill, and Gary M. Feinman

2009 The Archaeology of Environmental Change: Socionatural Legacies of Degradation and Resilience. Tucson: University of Arizona Press.

Foley, Stephen F., et al.

2013 The Palaeoanthropocene - The beginnings of anthropogenic environmental change. Anthropocene 3:83-88.

Harris, Trevor M.

2006 Scale as Artifact: GIS, Ecological Fallacy, and Archaeological Analysis. In Confronting scale in archaeology: issues of theory and practice. B.L. Molyneaux and G. Lock, eds. Pp. 39-53. New York: Springer.

Harrison, Ramona, and Ruth A. Maher

2014a Human Ecodynamics in the North Atlantic: A Collaborative Model of Humans and Nature through Space and Time. Lanham, MD: Lexington Books.

2014b Humans--A Force of Nature. In Human Ecodynamics in the North Atlantic: A Collaborative Model of Humans and Nature through Space and Time. R. Harrison and R.A. Maher, eds. Pp. 1-20. Lanham, MD: Lexington Books.

Hayden, D.

2012 "I HAVE SEEN THE FUTURE": Selling the Unsustainable City. Journal of Urban History 38(1):3-15.

Hicks, Megan, et al.

2014 Community and Conservation: Documenting Millennial Scale Sustainable Resource Use at Lake Mývatn Iceland. In Handbook of Historical Ecology and Applied Archaeology. Isendahl and D. Stump, eds. In press: Oxford Universtity Press.

Hilger, Ludwig, et al.

2015 Reconstruction of historic soil erosion rates in a small lake catchment of the Melrakkaslétta peninsula of northeast Iceland using tephrochronology and ground-based LiDAR data. Zeitschrift für Geomorphologie 59(2):243-263.

Hill, J. Brett

2009 What Difference Does Environmental Degradation Make? Change and its Significance in Transjordan. In The Archaeology of Environmental Change: Socionatural Legacies of Degradation and Resilience. C.T. Fisher, J.B. Hill, and G.M. Feinman, eds. Pp. 160-173. Tucson: University of Arizona Press.

Hodder, Ian, and Craig Cessford 
2004 Daily Practice and Social Memory at Çatalhöyük. American Antiquity 69(1):17-40.

Ingold, Tim

1993 The Temporality of the Landscape. World Archaeology 25(2):152-174.

IPCC

2014 Climate Change 2014: Synthesis Report. Contribution of Working Groups I, II and III to the Fifth Assessment Report of the Intergovernmental Panel on Climate Change. Geneva, Switzerland: IPCC.

Johnson, Matthew H.

2012 Phenomenological Approaches in Landscape Archaeology. Annual Review of Anthropology 41(1):269-284.

Kennett, Douglas J., and Timothy P. Beach

2013 Archeological and environmental lessons for the Anthropocene from the Classic Maya collapse. Anthropocene 4:88-100.

Kintigh, Keith W., et al.

2014 Grand Challenges for Archaeology. American Antiquity 79(1):5-24.

Klein, Naomi

2015 This Changes Everything: Capitalism vs. The Climate. New York: Simon \& Schuster.

Lane, Paul J.

2015 Archaeology in the age of the Anthropocene: A critical assessment of its scope and societal contributions. Journal of Field Archaeology 40(5):485-498.

Lansing, J. Stephen

2007 Priests and Programmers: Technologies of Power in the Engineered Lanscape of Bali. Princeton: Princeton University Press.

Larkin, Brian

2013 The Politics and Poetics of Infrastructure. Annual Review of Anthropology 42(1):327343.

Lefebvre, Henri

1991 The Production of Space. D. Nicholson-Smith, transl. Malden, MA: Blackwell.

Lentfer, Carol, Michael Therin, and Robin Torrence

Page 31 of $\mathbf{3 5}$ 
2002 Starch Grains and Environmental Reconstruction: a Modern Test Case from West New Britain, Papua New Guinea. Journal of Archaeological Science 29(7):687-698.

Lewis, S. L., and M. A. Maslin

2015 Defining the anthropocene. Nature 519(7542):171-80.

Lightfoot, Kent G., Antoinette Martinez, and Ann M. Schiff

1998 Daily Practice and Material Culture in Pluralistic Social Settings: An Archaeological Study of Culture Change and Persistence from Fort Ross, California. American Antiquity 63(2):199-222.

Logan, Amanda

2013 Cha(lle)nging Our Questions: Toward an Archaeology of Food Security. The SAA Archaeological Record November 2013:20-23.

McGovern, Thomas H., et al.

2007 Landscapes of Settlement in Northern Iceland: Historical Ecology of Human Impact and Climate Fluctuation on the Millennial Scale. American Anthropologist 109(1):27-51.

Melville, Elinor G. K.

1990 Environmental and Social Change in the Valle del Mezquital, Mexico, 1521-1600. Comparative Studies in Society and History 32(1):24-53.

Mitchell, Don

2003 Dead Labor and the Political Economy of Landscape - California Living, California Dying. In Handbook of Cultural Geography. S.P. K. Anderson, N. Thrift, ed. Pp. 233248. London: Sage.

Morton, Timothy

2013 Hyperobjects: Philosophy and Ecology After the End of the World. Minneapolis: University of Minnesota Press.

Mrozowski, Stephen A.

2006 Environments of History: Biological Dimensions of Historical Archaeology. In Historical Archaeology. M. Hall and S. Silliman, eds. Pp. 23-41: Blackwell.

2011 Pragmatism and the Relevancy of Archaeology for Contemporary Society. In Archaeology in Society: Its Relevance in the Modern World. M. Rockman and J. Flatman, eds. Pp. 239-256. New York: Springer.

Norgaard, Kari Marie 
2011 Living in Denial: Climate Change, Emotions, and Everyday Life. Cambridge: The MIT Press.

Ogilvie, A. E. J.

2010 Historical climatology, Climatic Change, and implications for climate science in the twenty-first century. Climatic Change 100(1):33-47.

Palsson, Gisli, et al.

2013 Reconceptualizing the 'Anthropos' in the Anthropocene: Integrating the social sciences and humanities in global environmental change research. Environmental Science \& Policy 28:3-13.

Redman, Charles L.

2005 Resilience Theory in Archaeology. American Anthropologist 107(1):70-77.

Redman, Charles L., Margaret C. Nelson, and Ann P. Kinzig

2009 The Resilience of Socioecological Landscapes: Lessons from the Hohokam. In The Archaeology of Environmental Change: Socionatural Legacies of Degradation and Resilience. C.T. Fisher, J.B. Hill, and G.M. Feinman, eds. Pp. 15-39. Tucson: University of Arizona Press.

Reitz, Elizabeth, and Myra Shackley

2012 Environmental Archaeology: Springer.

Rick, Torben C., et al.

2013 Archeology, deep history, and the human transformation of island ecosystems. Anthropocene 4:33-45.Robin, Cynthia

2006 Gender, Farming, and Long-Term Change: Maya Historical and Archaeological Perspectives. Current Anthropology 47(3):409-433.

Rockman, Marcy, and Joe Flatman

2012 Archaeology in Society: Its Relevance in the Modern World. New York: Springer.

Rull, Valentí, et al.

2013 Challenging Easter Island's collapse: the need for interdisciplinary synergies. Frontiers in Ecology and Evolution 1.

Smith, Kevin P.

1995 Landnám: The Settlement of Iceland in Archaeological and Historical Perspective. World Archaeology 26(3):319-347. 
Steffen, Will, et al.

2011 The Anthropocene: From Global Change to Planetary Stewardship. Ambio 40(7):739761.

Steinberg, John, Douglas J. Bolender, and Brian N. Damiata

in press The Viking Age Settlement Pattern of Langholt, North Iceland: Results of the Skagafjörður Archaeological Settlement Survey. Journal of Field Archaeology.

Steward, Julian

1955 The Concept and Method of Cultural Ecology. In Theory of Culture Change. Urbana, IL: University of Illinois Press.

Streeter, R., and A. J. Dugmore

2013 Anticipating land surface change. Proc Natl Acad Sci U S A 110(15):5779-84.

Streeter, R., et al.

2015 The onset of the palaeoanthropocene in Iceland: Changes in complex natural systems. The Holocene.

Stump, Daryl

2013 On Applied Archaeology, Indigenous Knowledge, and the Usable Past. Current Anthropology 54(3):268-298.

Thomson, Amanda M., and Ian A. Simpson

2006 Modeling Historic Rangeland Management and Grazing Pressures in Landscapes of Settlement. Human Ecology 35(2):151-168.

Pórarinsson, Sigurður

1944 Tefrokronologiska Studier På Island: Pjórsárdalur och Dess Förödelse [Tephrochronological Studies of Iceland]. Geografiska Annaler 26:1-217.

Thórhallsdóttir, Anna Guðrún, Árni Daníel Júlíusson, and Helga Ögmundardóttir

2013 The Sheep, the Market, and the Soil: Environmental Destruction in the Icelandic Highlands, 1880-1910. In Northscapes: History, Technology, and the Making of Northern Environments. D. Jørgensen and S. Sörlin, eds. Pp. 155-173. Vancouver: UBC Press.

Thurston, Tina L.

2009 Farming the Margins: On the Social Causes and Consequences of Soil-Management Strategies. In The Archaeology of Environmental Change: Socionatural Legacies of 
Degradation and Resilience. C.T. Fisher, B.J. Hill, and G.M. Feinman, eds. Pp. 106-134. Tucson: University of Arizona Press.

Van de Noort, Robert

2013 Climate Change Archaeology: Building Resilience from Research in the World's Coastal Wetlands. Oxford: Oxford University Press.

van der Leeuw, Sander E.

201415 Transforming Lessons from the Past into Lessons for the Future. Archeological Papers of the American Anthropological Association 24(1):215-231.

Vésteinsson, Orri, et al.

2014 Expensive errors or rational choices: the pioneer fringe in Late Viking Age Iceland. European Journal of Post-Classical Archaeologies 4:39-68.

Vésteinsson, Orri, and Thomas H. McGovern

2012 The Peopling of Iceland. Norwegian Archaeological Review 45(2):206-218.

Wilson, D. R.

1989 Alterations to Ridge and Furrow: Some Examples Illustrated. In The Rural Settlements of Medieval England: Studies Dedicated to Maurice Beresford and John Hurst. M. Aston, D. Austin, and C. Dyer, eds. Pp. 183-190. Oxford: Basil Blackwell.

Woodbridge, Jessie, et al.

2012 A spatial approach to upland vegetation change and human impact: the Aber Valley, Snowdonia. Environmental Archaeology 17(1):80-94.

Young, Marianne N., et al.

2007 Group Report: Future Scenarios of Human-Environment Systems. In Sustainability or Collapse? : An Integrated History and Future of People on Earth. R. Costanza, L. Graumlich, and W.L. Steffen, eds. Pp. 447-470. Cambridge, MA: MIT Press. 